Using Picea/Pinus Ratios from the Wilcox Pass Core, Jasper National Park, Alberta, to Investigate Holocene Timberline Fluctuations

Étude des fluctuations de la limite des arbres à l'Holocène par la mesure des taux de Picea et de Pinus présents dans une carotte prélevée à Wilcox Pass, parc national de Jasper, Alberta Studie der Fluktuationen der Baumgrenze im Holozän unter Nutzung der Picea/Pinus-Anteile der Wilcox Pass-Probe, Jasper Nationalpark, Alberta

\author{
Alwynne B. Beaudoin
}

Volume 40, numéro 2, 1986

URI : https://id.erudit.org/iderudit/032634ar

DOI : https://doi.org/10.7202/032634ar

\section{Aller au sommaire du numéro}

\section{Éditeur(s)}

Les Presses de l'Université de Montréal

ISSN

0705-7199 (imprimé)

1492-143X (numérique)

Découvrir la revue

Citer cet article

Beaudoin, A. B. (1986). Using Picea/Pinus Ratios from the Wilcox Pass Core, Jasper National Park, Alberta, to Investigate Holocene Timberline Fluctuations. Géographie physique et Quaternaire, 40(2), 145-152.

https://doi.org/10.7202/032634ar

\section{Résumé de l'article}

On a pu évaluer les différentes altitudes de la limite des arbres en comparant les taux de Picea et de Pinus présents dans la carotte, qui a été datée au radiocarbone et par tephrochronologie, avec les taux actuels enregistrés dans des échantillons de surface le long d'un tracé qui s'étend de Wilcox Pass, en végétation alpine, jusqu'à Sunwapta Pass tout près, en forêt subalpine. Les plus forts taux de pollen observés dans la carotte que dans les échantillons de surface démontrent que la limite des arbres était à une altitude supérieure entre environ 6540 et 1480 BP que maintenant, avec un minimum vers 4210 BP. Par contre, la limite des arbres était inférieure à maintenant entre environ 1480 et $540 \mathrm{BP}$, pour s'élever de nouveau après $540 \mathrm{BP}$. Ces observations concordent en grande partie avec d'autres études paléoenvironnementales effectuées dans la région. La technique ne peut toutefois s'appliquer qu'à partir du moment où le même type de végétation que celui que l'on trouve aujourd'hui s'est déjà manifesté. Pour cette raison, les taux de Picea et de Pinus enregistrés dans la carotte de Wilcox Pass avant 6540 BP environ ne peuvent être interprétés à l'aide de cette méthode.
Tous droits réservés @ Les Presses de l'Université de Montréal, 1986
Ce document est protégé par la loi sur le droit d'auteur. L’utilisation des services d’Érudit (y compris la reproduction) est assujettie à sa politique d'utilisation que vous pouvez consulter en ligne.

https://apropos.erudit.org/fr/usagers/politique-dutilisation/ 


\title{
USING PICEA/PINUS RATIOS FROM THE WILCOX PASS CORE, JASPER NATIONAL PARK, ALBERTA, TO INVESTIGATE HOLOCENE TIMBERLINE FLUCTUATIONS*
}

\author{
Alwynne B. BEAUDOIN ${ }^{\star \star}$, Department of Geography, University of Western Ontario, London, Ontario N6A 5C2.
}

\begin{abstract}
Holocene timberline fluctuations are investigated using Picea/Pinus ratios from the tephra and radiocarbon-dated Wilcox Pass Core $\left(52^{\circ} 14^{\prime} \mathrm{N}, 117^{\circ} 13^{\prime} \mathrm{W}\right)$. Timberline elevations are calibrated by comparing Picea/ Pinus ratios from the core with modern ratios obtained in surface samples of a transect from alpine vegetation in Wilcox Pass into subalpine forest in adjacent Sunwapta Pass. Ratios higher than present ratios from the site imply higher-than-present timberline elevation. The Picea/Pinus ratios imply higherthan-present timberline between ca. 6540$1480 \mathrm{yr}$ BP, with a minimum about $4210 \mathrm{yr}$ $\mathrm{BP}$, while timberline was lower than present between ca. $1480-540 \mathrm{yr}$ BP and increased in elevation after 540 yr BP. This record substantially agrees with other palaeoenvironmental records from the region. The main limitation on the technique is that it can only be applied since similar-to-present vegetation became established in the area. Hence, Picea/ Pinus ratios from the Wilcox Pass core prior to ca. $6540 \mathrm{yr}$ BP cannot readily be interpreted by this method.
\end{abstract}

RÉSUMÉ Étude des fluctuations de la limite des arbres à l'Holocène par la mesure des taux de Picea et de Pinus présents dans une carotte prélevée à Wilcox Pass, parc national de Jasper, Alberta. On a pu évaluer les différentes altitudes de la limite des arbres en comparant les taux de Picea et de Pinus présents dans la carotte, qui a été datée au radiocarbone et par tephrochronologie, avec les taux actuels enregistrés dans des échantillons de surface le long d'un tracé qui s'étend de Wilcox Pass, en végétation alpine, jusqu'à Sunwapta Pass tout près, en forêt subalpine. Les plus forts taux de pollen observés dans la carotte que dans les échantillons de surface démontrent que la limite des arbres était à une altitude supérieure entre environ 6540 et $1480 \mathrm{BP}$ que maintenant, avec un minimum vers 4210 BP. Par contre, la limite des arbres était inférieure à maintenant entre environ 1480 et $540 \mathrm{BP}$, pour s'élever de nouveau après $540 \mathrm{BP}$. Ces observations concordent en grande partie avec d'autres études paléoenvironnementales effectuées dans la région. La technique ne peut toutefois s'appliquer qu'à partir du moment où le même type de végétation que celui que l'on trouve aujourd'hui s'est déjà manifesté. Pour cette raison, les taux de Picea et de Pinus enregistrés dans la carotte de Wilcox Pass avant 6540 BP environ ne peuvent être interprétés à l'aide de cette méthode.
ZUSAMMENFASSUNG Studie der Fluktuationen der Baumgrenze im Holozän unter Nutzung der Picea/Pinus-Anteile der Wilcox Pass-Probe, Jasper Nationalpark, Alberta. Die Fluktuationen der Baumgrenze im Holozän werden unter Nutzung der Picea/PinusAnteile des mittels Tephra und Radiokarbon datierten Wilcox Pass-Probe $\left(117^{\circ} 13^{\prime} \mathrm{W}\right.$, $\left.52^{\circ} 14^{\prime} \mathrm{N}\right)$ untersucht. Die verschiedenen Höhen der Baumgrenze wurden kalibriert, indem man Picea/Pinus-Anteile der Probe verglich mit gegenwärtigen Anteilen, welche aus Oberflächenproben entlang einem Längsschnitt gewonnen wurden, der von der alpinen Vegetation im Wilcox Pass bis zum subalpinen Wald im angrenzenden Sunwapta Pass reicht. Höhere Anteile als die gegenwärtigen von dieser Stelle bedeuten, da $\beta$ die Baumgrenze höher war als gegenwärtig. Die Picea/Pinus-Anteile lassen für die Zeit zwischen etwa 6540 - 1480 Jahren v.u.Z. auf eine höhere Baumgrenze als gegenwärtig schließen mit einem Minimum vor etwa 4210 Jahren v.u.Z., als die Baumgrenze niedriger war als heute zwischen etwa $1480-540$ Jahren v.u.Z. und dann nach 540 Jahren v.u.Z. wieder anstieg. Dieser Beleg stimmt im wesentlichen mit anderen Paläo-Umwelt-Belegen von diesem Gebiet überein. Diese Technik hat ihre Grenze darin, da $\beta$ sie nur ab dem Zeitpunkt eingesetzt werden kann, wo sich in diesem Gebiet eine Vegetation durchsetzte, die der heutigen gleicht. Folglich können Picea/Pinus-Anteile der Wilcox Pass-Probe, die aus der Zeit von vor 6540 Jahren v.u.Z. stammen, nicht ohne weiteres mit dieser Methode interpretiert werden.

\footnotetext{
* Contribution du Premier Symposium de la CANQUA, sous la direction de René W. Barendregt

** Present address: Archaeological Survey of Alberta, 8820-112th Street, Edmonton, Alberta T6G 2P8
} 


\section{INTRODUCTION}

This paper explores the use of pollen ratios to infer Holocene timberline fluctuations by a case study of a core from Wilcox Pass, an alpine site in Jasper National Part, Alberta (Figs. 1 and 2). The methodology of the investigation of timberline fluctuations, as discussed by MAHER $(1963 ; 1972)$ and KEARNEY (1981), involves firstly calibrating the position of the present timberline with respect to the sample site by examining modern pollen ratios derived from an elevational transect (Fig. 3) and, secondly, comparing the apparent elevation of the site (based on pollen ratios from the core) to the present elevation of the site. Apparent elevation is obtained by matching the pollen ratio from the sample to the appropriate elevation from the modern pollen record (Figs. 3 and 4). Higherthan-present ratios give a lower apparent site elevation but indicate that timberline was higher than present (Fig. 4 b). Conversely, lower-than-present ratios give a higher apparent site elevation and indicate that timberline was lower than present (Fig. 4 c). Hence, Picea/Pinus pollen ratios from the Wilcox Pass core are compared with modern ratios from a transect from alpine areas in Wilcox Pass into subalpine firEngelmann spruce forest in adjacent Sunwapta Pass (Figs. 2 and 3). It is assumed that Picea pollen is derived mainly from

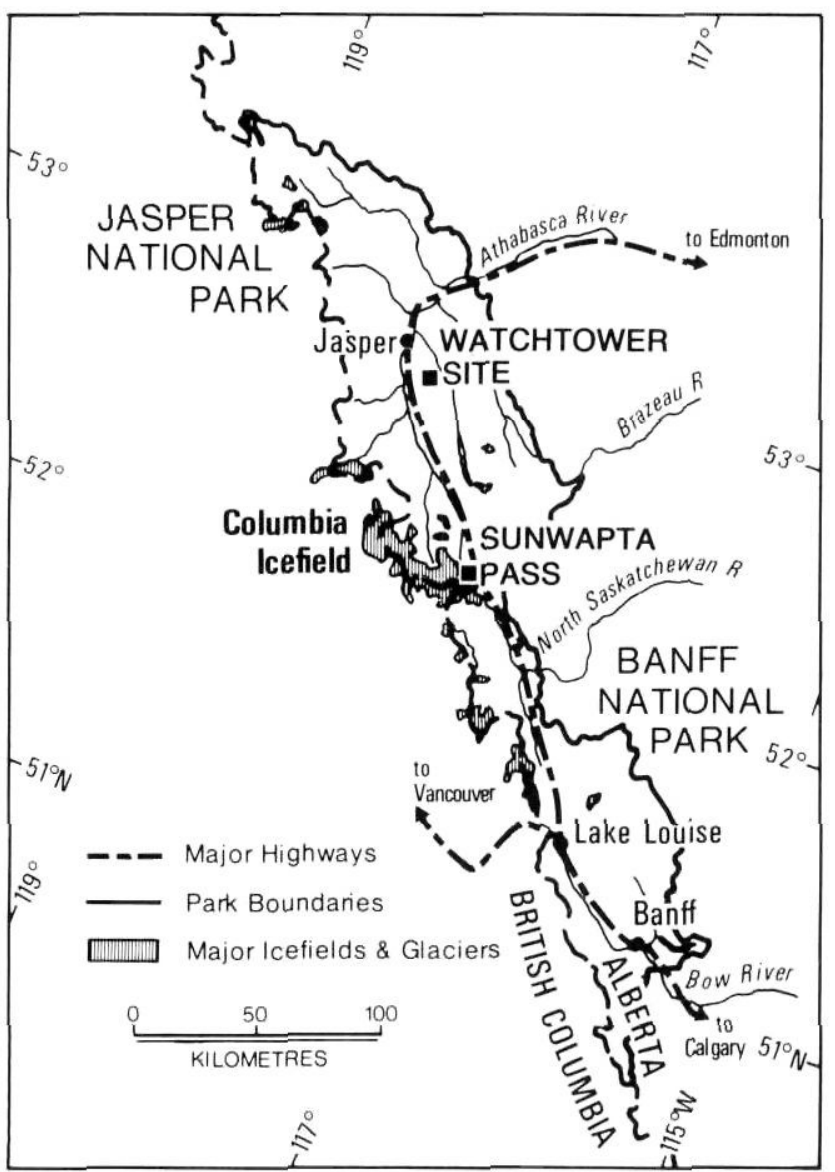

FIGURE 1. Location of the Sunwapta Pass area, Jasper National Park.

Localisation de la région de Sunwapta Pass, parc national de Jasper. the local subalpine forest vegetation, whereas diploxylon type Pinus pollen, derived principally from lodgepole pine, has a more regional source. Hence, an increase in Picea/Pinus ratios at the alpine site implies that the subalpine forest was closer to the site, therefore that timberline elevation increased (Fig. 4). KEARNEY $(1981,1982)$, working in Jasper National Park, found a correlation between seedling establishment at timberline and warmer than average mean minimum summer temperatures. This suggests that higher timberlines reflect times of warmer climate (see also LaMARCHE, 1973). However, lags in vegetation response to climatic change may mean that present timberline position may not be reflecting present temperatures directly, but conditions some years previously when seedling establishment occurred. With suitable calibration, this technique might yield quantitative estimates of timberline position and possibly of temperature changes. Limitations on the technique will also be examined in this paper.

\section{DESCRIPTION OF THE WILCOX PASS AND SUNWAPTA PASS AREA}

The Wilcox Pass and Sunwapta Pass area is situated in the Main Ranges of the Canadian Rockies, adjacent to the Athabasca Glacier, an outlet from the Columbia Icefield (Figs. 1 and 2). Bedrock is mainly Ordovician limestone and dolomite (ASPLER, 1975) which is exposed in ridges in Wilcox Pass. Although close to the Columbia Icefield, the area has not been glaciated since the early Holocene. In the middle $\mathrm{Ca}$ nadian Rockies, LUCKMAN and OSBORN (1979) found consistent evidence for only two glacial advances, the Crowfoot (Late Wisconsinan/early Holocene) and Cavell (Late Neoglacial) advances, subsequent to the Wisconsinan deglaciation. A large, tree-covered ridge adjacent to recent deposits of the Athabasca Glacier has been attributed to the Crowfoot Advance (LUCKMAN and OSBORN, 1979; Fig. 2). The oldest radiocarbon date yet obtained from Sunwapta Pass, outside the Crowfoot limit, is $8100 \pm 100{ }^{14} \mathrm{C}$ yr BP (GSC-2589; LUCKMAN et al., 1977). Wilcox Pass, further north and at a higher elevation (Fig. 2) has been ice-free throughout the Holocene, based on a $9600 \pm 305{ }^{14} \mathrm{C}$ yr BP (GX-8785) radiocarbon date from the Wilcox Pass core.

The vegetation of the area was recently described as part of a biophysical inventory of Jasper and Banff National parks (HOLLAND and COEN, 1982). Basically three vegetation zones occur (Fig. 2). The valley floor of Sunwapta Pass is occupied mainly by bogs, vegetated by sedges (Cyperaceae) and mosses with shrubby vegetation, principally willows and dwarf birch (Salix spp. and Betula glandulosa) on more elevated drier sites. Subalpine forest, dominated by Engelmann spruce and subalpine fir (Picea engelmannii and Abies lasiocarpa) with an understory mainly of willows and dwart birch, occupies the valley sides. Lodgepole pine (Pinus contorta), although present in the area, does not form extensive pure stands. Some whitebark pine (Pinus albicaulis) is also found, mainly near timberline. Above the krummholz zone, alpine vegetation occurs in Wilcox Pass, with Salix and Dryas as major components. Present timberline is found below the lip of Wilcox Pass at about $2080 \mathrm{~m}$, while treeline occurs at about $2290 \mathrm{~m}$. 


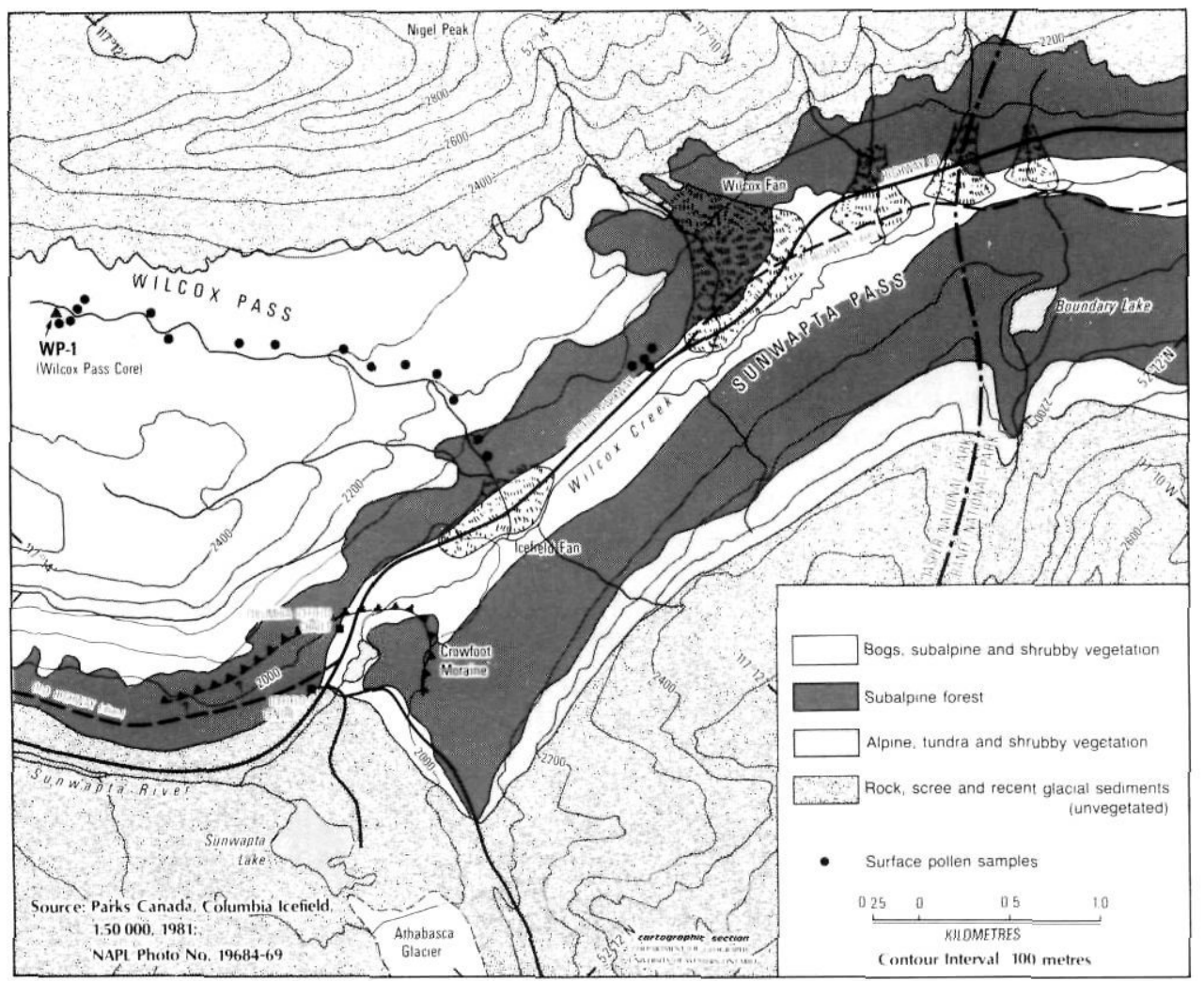

FIGURE 2. The Sunwapta Pass area showing surface pollen sampling sites, vegetation zones and the location of the Wilcox Pass core.

Carte de la région de Sunwapta Pass qui montre les sites d'échantillonnage du pollen de surface, les zones de végétation et la localisation du site de carottage de Wilcox Pass.

\section{METHODS}

The $2.74 \mathrm{~m}$ Wilcox Pass core was obtained, using a modified Livingstone corer, from a shallow bedrock basin. The deposits in the lower part of the core are dominantly clastic, mainly silty, and carbonate-rich, becoming more organic towards the surface. Due to limited throughput of water and lack of significant sediment source upstream, the site has probably been unaffected by large influxes of sediment during the Holocene. The vegetation history inferred from the pollen record of the Wilcox Pass core is described in detail elsewhere (BEAUDOIN, 1984).

Dating control for the Wilcox Pass record is provided by radiocarbon dates and tephra. Two radiocarbon dates were obtained from organic material from the core: $540 \pm 50{ }^{14} \mathrm{C} \mathrm{yr}$ BP (Beta-6806) at $18-22 \mathrm{~cm}$ depth and $9600 \pm 305{ }^{14} \mathrm{C} \mathrm{yr}$ BP (GX-8785) at $192-200 \mathrm{~cm}$ depth. Tephra first occurs in quantity at $173-175 \mathrm{~cm}$ depth (Fig. 5). This tephra resembles Mazama tephra, based on electron microprobe analysis of glass-encased titanomagnetites and glass shard morphology (BEAUDOIN, 1984; BEAUDOIN and KING, 1986). The Mazama tephra in the western Cordillera is dated at $6700 \mathrm{yr} \mathrm{BP}$ (WESTGATE and GORTON, 1981). Dates for intermediate parts of the record are estimated by assuming constant sedimentation rates between the dated layers.

Present timberline position is calibrated by examining pollen ratios derived from a modern pollen transect (Figs. 2 and 3). Modern pollen spectra are obtained from moss polsters. Pollen was prepared for microscope examination using standard chemical methods (FAEGRI and IVERSEN, 1975; BATES et al., 1978; BEAUDOIN, 1984), and the residues were stained with safranin and mounted in silicone oil (2000 cs viscosity). Samples were examined, using a Wild-Leitz SM-Lux microscope, at magnifications $400 \mathrm{X}$ and 1000X. Pollen and spores were identified using a reference collection, belonging to $K$. B. Cawker, and several keys, including KAPP (1969), McANDREWS et al. (1973), and BASSETT et al. (1978). Pollen sums usually exceed 300 grains.

Pine pollen was identified as haploxylon or diploxylon type where possible; types distinguished by the presence/absence of distal verrucae (TING, 1966) were assigned to subgenera (BAKER, 1976). It is assumed that both types degrade equally and that the proportions found in the identified count may be applied to the pine count as a whole. When calculating Picea/ Pinus ratios, the Pinus values are "corrected" for the amount of haploxylon type pine pollen, so that the ratios reflect only the amount of diploxylon type pine pollen.

\section{CALIBRATION OF THE PRESENT TIMBERLINE}

Examination of Abies/Pinus, (Abies + Picea)/Pinus and Picea/Pinus ratios, derived from 71 surface samples from throughout the Wilcox Pass and Sunwapta Pass area, showed that Picea/Pinus ratios are most sensitive to change in vegetation type (BEAUDOIN, 1984). Picea/Pinus ratios are generally $>0.8$ in the subalpine forest and $<0.8$ on the subalpine bogs in Sunwapta Pass or in alpine areas in Wilcox Pass. Samples in the krummholz zone, between treeline and timberline, have lower ratios which more closely resemble the ratios from more open areas above treeline than those from 
the subalpine forest. The Picea/Pinus ratios, therefore, display a recognisable relationship with vegetation types and may be used to infer elevation above the present timberline. When the Picea/Pinus ratios from the Wilcox Pass transect are plotted against elevation (Fig. 3) a clear trend is seen, although with some variability; the cluster of points at $2350 \mathrm{~m}$ reflects the crest of the Pass while the few points on this transect between ca. 2250 and $2100 \mathrm{~m}$ reflect the steep rocky slopes at the lip of Wilcox Pass.

Several assumptions are inherent in this method. It is assumed that the Picea pollen is derived locally from the subalpine forest whereas the Pinus pollen is derived mainly from regional sources and is acting as an almost constant background input. This assumption seems reasonable given the wellknown tendency for pine pollen to be over-represented in pollen spectra and to be found at great distances from its source (FAEGRI and IVERSEN, 1975), and the extensive areas of lodgepole pine-dominated forest found at lower elevations (see HOLLAND and COEN, 1982). However, the wind pattern in mountains is highly variable (JANZ and STORR, 1977) and could influence, for example, the distance that the rapidly-settling Picea pollen is carried upslope. For instance, in a study of pollen dispersal in the Swiss Alps, MARKGRAF (1980) found that pollen from low elevations showed a relative increase at high elevations due to the low pollen productivity at high elevations and the upslope wind direction.

Another fundamental assumption is that the relationship between slope and elevation is relatively constant and therefore that elevation carı be used as a surrogate measure of distance from timberline. In Wilcox Pass, slope is not constant (Fig. 2) and hence in this case elevation is not a simple surrogate measure for distance from the timberline. The forest generally inhabits the steeper valley side slopes whereas the floors of both Wilcox Pass and Sunwapta Pass have relatively gentle slopes (Fig. 2). Also, the configuration of the slope is likely to affect wind patterns and microclimate, which thereby would influence tree distribution. Thus, where topographic discontinuities are involved, these may interact with local environmental factors to influence vegetation distribution, independent of elevation relationships. This analysis is therefore site-specific; using Picea/Pinus ratios from one area to interpret records from a different area would be unwise.

Increased Pinus relative to Picea pollen may be related to fire. Fire incidence may be related to climate but at one remove further than direct climatic influence on the vegetation. Moreover, in this relatively marginal area, forest may take a long time to re-establish after a fire (HABEK and MUTCH, 1973), and thus timberline may be lower for some considerable time. Fire incidence in the settled areas, for example, around Jasper townsite, is likely to have been much greater in the early years of settlement in the last century and would also have been increased by the construction of the railway (NELSON and BYRNE, 1969). Therefore lodgepole pine is likely to be more dominant in the regional vegetation in some areas now than in the past. For instance, KEARNEY (1981) did not use the modern pollen data from the Signal Mountain transect, near Jasper townsite, because of the recent fire history of that area. Thus if lodgepole pine is more prevalent in the

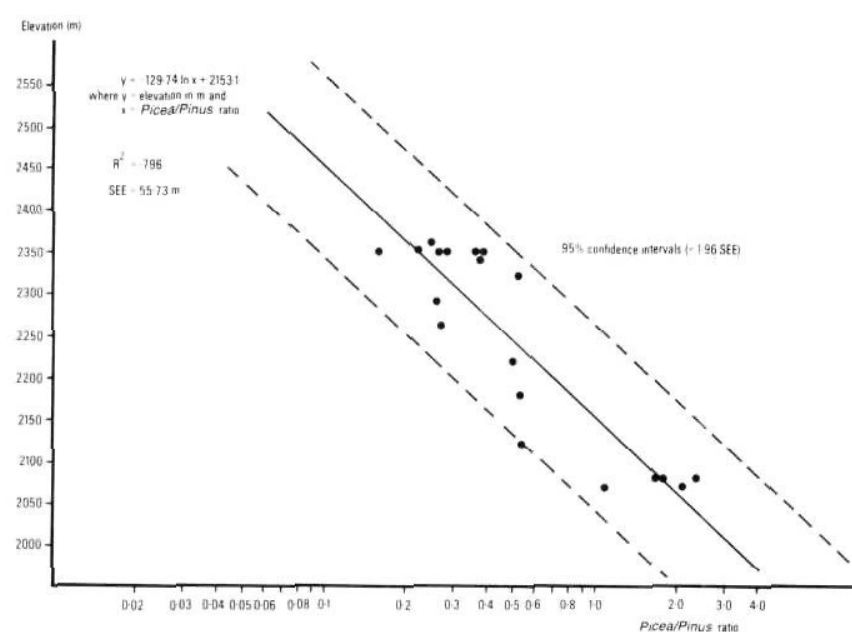

FIGURE 3. Variations in the Picea/Pinus ratios with elevation for the surface pollen transect from Wilcox Pass.

Variations des taux de Picea et de Pinus selon l'altitude le long du tracé de Wilcox Pass.

regional vegetation now than in the past, the past Picea/Pinus ratios would be higher than present ratios, leading to false implications of higher timberline and therefore warmer conditions in the past as compared to the present. However, in the Sunwapta Pass area there is no evidence for recent major fires leading to increased extent of lodgepole pine and therefore the present ratios are probably not unduly influenced by this factor.

\section{HOLOCENE TIMBERLINE FLUCTUATIONS INFERRED FROM THE WILCOX PASS CORE}

The ratio/elevation diagram for the present Picea/Pinus ratios (Fig. 4) is used to plot the apparent elevation for the Picea/Pinus ratios from the Wilcox Pass core (Fig. 5). Using the equation developed from the modern samples, the upper sample from the core predicts the present apparent elevation of the site quite well, giving an estimate only $20 \mathrm{~m}$ higher than the actual elevation.

Four main phases of Picea/Pinus ratio fluctuations can be identified from this data. Low Picea/Pinus ratios $(<.15)$ occur from the base of the record to about $195 \mathrm{~cm}$ depth, including pollen zones WP1, WP2, and the lower part of Zone WP3. This phase occurs below the $9600 \pm 305 \mathrm{yr}$ BP (GX-8785) radiocarbon date. Generally high ratios (>.2) occur from 195$43 \mathrm{~cm}$ depth. Throughout this phase, a general trend can be seen from very high ratios $(>.25)$ between $195-170 \mathrm{~cm}$ depth, with a gradual decline to .21 ratio at $111.5 \mathrm{~cm}$ depth, followed by an increase to $.29-.34$ ratios between $75-43 \mathrm{~cm}$ depth. This general trend is interrupted by a ratio of .94 at $175.5 \mathrm{~cm}$ depth, which reflects the high amount of haploxylon type pine pollen in this sample. The inferred dates for this phase are 9600-1480 yr BP and it includes most of Zones WP3, WP4, and the lower part of Zone WP5. This is followed by a short phase, between $43-20 \mathrm{~cm}$ depth, during which the ratios fell to a low of .08. This phase has an estimated age of 1480 $540 \mathrm{yr}$ BP. Finally, from $20 \mathrm{~cm}$ to the surface, from $540 \mathrm{yr}$ BP 

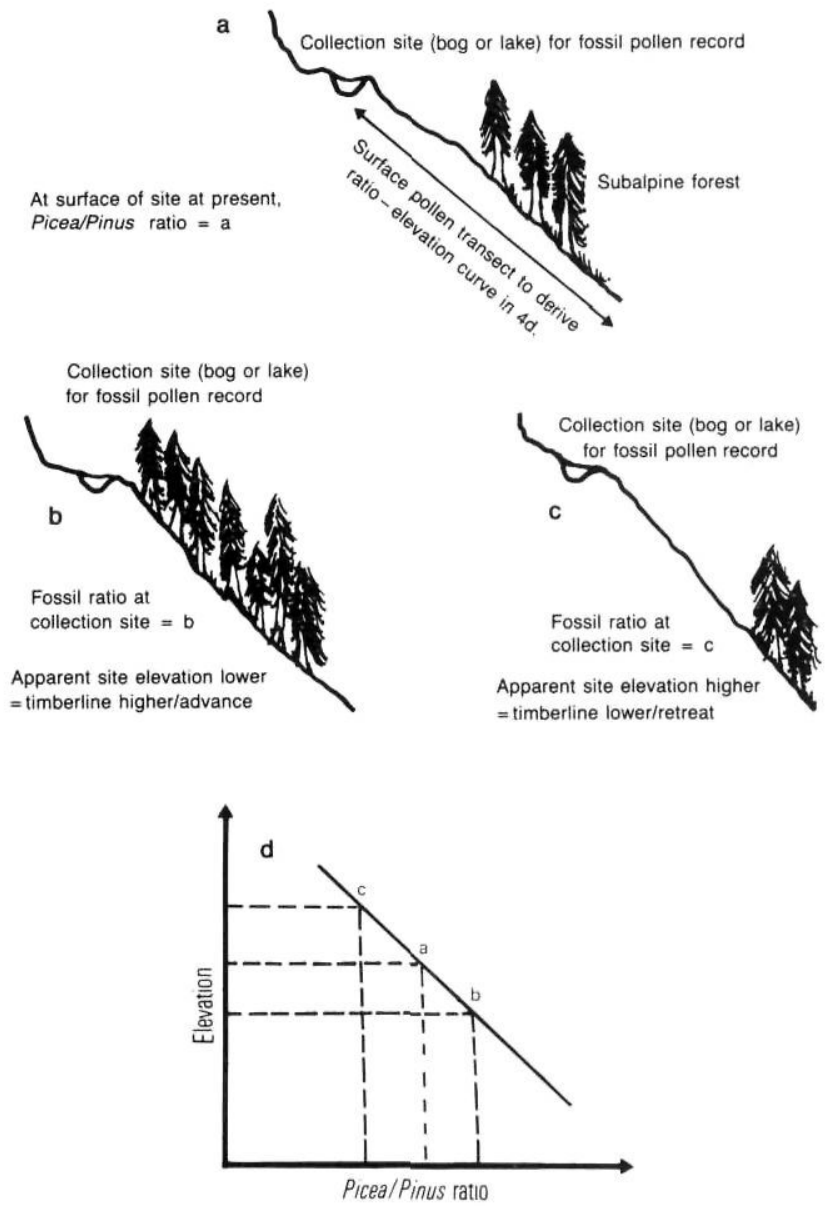

FIGURE 4. Schematic diagram showing relationships between elevation and ratios with timberline fluctuations.

Diagramme schématisé montrant les relations qu'entretiennent l'altitude et les taux de pollen avec les fluctuations de la limite des arbres.

to the present, Picea/Pinus ratios are relatively high. This phase includes the upper part of Zone WP5.

Not all these phases should be interpreted as reflecting climatically-induced timberline fluctuations. The calibration curve derived from present vegetation can only be used to interpret the past record since similar vegetation to present became established in the area. For instance, the complete pollen record from the Wilcox Pass core (BEAUDOIN, 1984) indicates that the vegetation of the early zones (WP1, WP2 and WP3) was different to present vegetation. In Zone WP1, for example, a pollen assemblage dominated by Artemisia implies that the landscape was probably almost treeless. In Zones WP1 and WP2, Picea/Pinus ratios imply a higher apparent site elevation and therefore cooler conditions. But the lack of Picea is probably related to site instability, lack of available suitable soils and sites, and slower migration of spruce into the area. However, large amounts (ca. $85 \%$ ) of Pinus (mainly diploxylon type) pollen in Zone WP2 are associated with small amounts (ca. $1 \%$ ) of Arceuthobium pollen. Because Arceuthobium is a parasite on pine and its pollen is not usually far dispersed from the parent plant (GREGOR

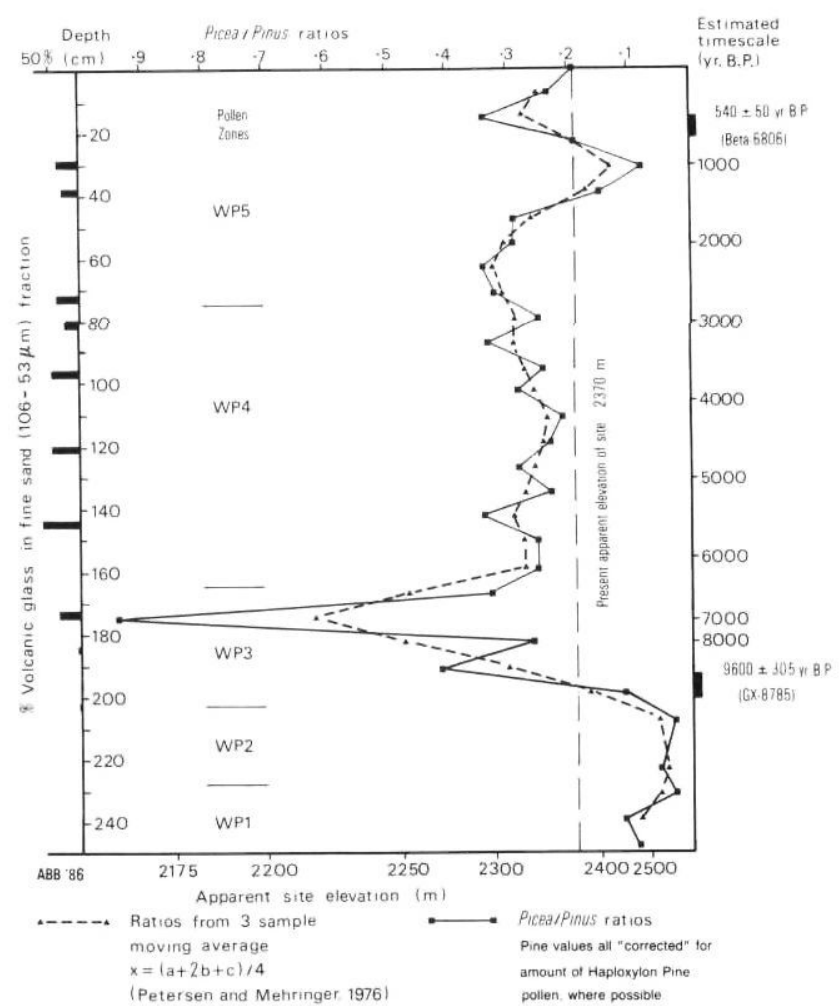

FIGURE 5. Apparent site elevations based on Picea/Pinus ratios from the Wilcox Pass core.

Altitudes probables des sites fondées sur les taux de Picea et de Pinus enregistrés dans la carotte de Wilcox Pass.

et al., 1974), this implies that trees must have been closer to the site than present. The overall view thus implies a higherthan-present timberline and possibly warmer than present conditions during Zone WP2; a contrasting conclusion to that obtained by examining the Picea/Pinus ratios alone. Therefore, palaeoclimatic inferences solely from the ratios are misleading as climate is probably not the main limiting factor controlling the relative amounts of Pinus and Picea in Zones WP1 and WP2. Similarly, in Zone WP3, the Picea/Pinus ratios imply higher timberline, but, from the pollen record, haploxylon pine was a major component of the vegetation at this time (BEAUDOIN, 1984). Hence, the forest composition was not the same as at present and the ratios alter because the Pinus values are "corrected" for the amount of haploxylon pine. However, from the later part of Zone WP3, from ca. $170 \mathrm{~cm}$ depth, and during Zones WP4 and WP5, vegetation similar to present vegetation occurred in the area, and therefore fluctuations in the Picea/Pinus ratios may have interpretative significance in terms of timberline fluctuations and possibly climate.

The generally higher-than-present ratios from $170-43 \mathrm{~cm}$ depth imply a prolonged period of middle Holocene higherthen-present timberline. A sustained period of middle Holocene higher-than-present timberline has been reported from other areas, for example, by LaMARCHE (1973) from the White Mountain area of California. If upper timberline position is related to summer temperatures, this implies that, for much of the Holocene (at least from ca. 6540-1480 yr BP), summer 
temperatures in the Wilcox Pass and Sunwapta Pass area have generally been warmer than present.

However, within this phase, conditions did not remain uniform. The general decline in ratios between $170 \mathrm{ca} .111 .5 \mathrm{~cm}$ depth, with an estimated age of $6540-4210 \mathrm{yr}$ BP, imply a gradually falling timberline with deteriorating conditions and possibly cooler temperatures. Other environmental records from the Canadian Rockies show a change from an early Holocene phase of maximum warmth to colder and wetter conditions, after the Mazama ash fall, around $6000 \mathrm{yr}$ BP (see OSBORN, 1982; KEARNEY, 1981). Moreover, recent radiocarbon dates from the Boundary Glacier, an outlet from the Columbia Icefield about $5 \mathrm{~km}$ southeast of Wilcox Pass, suggest that a Neoglacial ice advance occurred ca. $4000 \mathrm{yr}$ BP (GARDNER and JONES, 1985). The lower ratios ca. $4000-4500 \mathrm{yr} \mathrm{BP}$ in this record correlate well with these observations.

From the low ratio at $111.5 \mathrm{~cm}$ depth, ratios gradually increase to a maximum of .34 at $63.5 \mathrm{~cm}$ depth, with an estimated age of $2290 \mathrm{yr}$ BP. This implies a gradual rise in timberline elevation, possibly related to a warming trend. OSBORN (1982) cites evidence which suggests a higher-thanpresent timberline at Peyto Glacier just prior to $2880 \pm 170$ ${ }^{14} \mathrm{C}$ yr BP (GSC-1155). KEARNEY (1981) also suggests warmer than present temperatures ca. $3330 \mathrm{yr}$ BP followed by a transition to cooler and wetter conditions after ca. $1700 \mathrm{yr}$. $\mathrm{BP}$ from analysis of the Maligne Lake core.

Picea/Pinus ratios have been more variable during Zone WP5, implying that timberline elevations have been more variable in the last two millenia. This correlates with other records, e.g. KEARNEY (1981), which suggest that the late Holocene has become colder and/or wetter. The low ratio at $31.5 \mathrm{~cm}$ depth, with an estimated age of $1020 \mathrm{yr}$ BP implies a low timberline phase. This is inconsistent with the occurrence of snags on the slope behind the Icefield Chalet (LUCKMAN, 1982; Fig. 2) which suggests higher-than-present timberline at this time. A similar discrepancy between pollen and macrofossil evidence was noted by ANDREWS et al. (1975) in the San Juan Mountains. The apparent discrepancy may be due to different dating control for the two sets of evidence. Alternatively, the apparent timberline retreat may be a response to some factor other than climate. However, some climatic fluctuations appear to occur quite rapidly, for example, studying tree-limit fluctuations in Scandinavia, KARLEN (1983) found evidence of glacier advances ca. 1200-1000 yr BP while wide tree rings suggested that the climate was warmer until $1250 \mathrm{yr}$ BP and between 1000-900 yr BP. With substantial changes on the scale of only a few hundred years, discrepancies between different environmental indicators, which have different response times, might be expected.

Timberline fluctuations may be related to climatic change and, specifically, temperature fluctuations, although other climatic components and environmental factors cannot be ruled out. For example, higher summer temperatures, possibly with a decrease in precipitation, might lead to moisture deficiency for trees growing on the shallow and freely-draining soils near the upper timberline in Sunwapta Pass. This might result in a lowering of timberline at times of higher temperatures. However, KEARNEY $(1981,1982)$ found that seedling establishment in Sunwapta Pass was positively correlated with recent warmer mean minimum summer temperatures.

\section{COMPARISON OF THE WILCOX PASS AND WATCHTOWER BASIN RECORDS}

Another timberline fluctuation record from Jasper National Park is available from Watchtower Basin (Fig. 1; KEARNEY, 1981; KEARNEY and LUCKMAN, 1983). The Wilcox and Watchtower records show several similarities. The early part of the Wilcox Pass record predates the Watchtower record. The base of the Watchtower record is estimated at ca. 81008500 yr BP (KEARNEY and LUCKMAN, 1983). Both records show an early Holocene phase of higher-than-present ratios. In the Watchtower record this phase lasted from about 8500 to $5900 \mathrm{yr}$ BP but was interrupted by timberline retreat (= lower ratios) at about $6900 \mathrm{yr}$ BP (KEARNEY and LUCKMAN, 1983). The second phase of higher-than-present timberline, between ca. 6700-5900 yr BP, appeared at least as warm as the earlier phase, judging by the apparent elevation data (KEARNEY and LUCKMAN, 1983). In the Wilcox Pass record, the early high ratios cannot be interpreted in terms of timberline elevations. However, the Wilcox Pass record does indicate that timberline was higher-than-present when subalpine forest became established in the area towards the close of Zone WP3, ca. 6540 yr BP (Fig. 5).

The Wilcox Pass record shows decreasing timberline elevations between $6540-4210 \mathrm{yr}$ BP, followed by increasing timberline elevations to $1480 \mathrm{yr} \mathrm{BP}$, culminating at about $2300 \mathrm{yr}$ BP. Timberline fell quite sharply after $1480 \mathrm{yr}$ BP. This middle Holocene record appears somewhat different from that recorded by the Watchtower Basin. However, the period from 5900-ca. $1600 \mathrm{yr} \mathrm{BP}$ is a fairly short segment of the Watchtower record, about $10 \mathrm{~cm}$ of sediment, reflecting decreased sedimentation rates (KEARNEY and LUCKMAN, 1983). Even in this compressed record, timberline was apparently higher at the close of this interval (KEARNEY and LUCKMAN, 1983), which matches the Wilcox Pass record at this time.

Both records show substantial timberline retreat after ca. $1600 \mathrm{yr}$ BP. In the Watchtower Basin, two brief reversals of this trend occurred at ca. 1000 and $500 \mathrm{yr} \mathrm{BP}$, while timberlines reached their lowest recorded elevation sometime after $500 \mathrm{yr}$ BP (KEARNEY and LUCKMAN, 1983). In the Wilcox Pass record only one reversal is seen, at about $430 \mathrm{yr} B P$ when timberlines were apparently at least as high as during the middle Holocene. Timberlines reached their lowest elevation since the initial part of the record at ca. $1020 \mathrm{yr}$ BP.

It is difficult to assess the impact of local conditions and site differences on the timberline fluctuation records. Sitespecific factors may account for the differences in the records in the middle Holocene. For instance, evidence of past higher timberline in the Watchtower Basin and Maligne Pass was supported by logs recovered from the sites (KEARNEY and LUCKMAN, 1983). No such evidence has been found in Wilcox Pass. Wilcox Pass contains shallow soils and bedrock outcrops. 
Thus higher timberlines may have been controlled not only by temperature limitations but also by edaphic factors and site availability. The Wilcox Pass core was interpreted using Picea/Pinus ratios, whereas KEARNEY and LUCKMAN (1983) used Abies/Pinus ratios to interpret the Watchtower Basin record. The response of Picea and Abies to climatic changes may differ. This might explain some variation between the records.

Overall, however, the timberline fluctuation records from Wilcox Pass and Watchtower Basin match quite well. This suggests that generally the timberline fluctuations are reflecting regional climatic trends.

\section{ACKNOWLEDGEMENTS}

This study was supported by the Natural Sciences and Engineering Research Council in the form of an operating grant to R. H. King. I wish to thank R. H. King, Y. Beaudoin, the students who helped with sampling in 1980, and K. B. Cawker for the loan of his pollen reference collection. Thanks to Parks Canada for permission to carry out fieldwork in Jasper National Park. I am grateful to B. H. Luckman for comments on earlier versions of this paper.

\section{REFERENCES}

ANDREWS, J. T., CARRARA, P. E., KING, F. B., and STUCKENRATH, R. (1975): Holocene environmental changes in the alpine zone, northern San Juan Mountains, Colorado: evidence from bog stratigraphy and palynology, Quaternary Research, Vol. 5, p. 173-197.

ASPLER, L. (1975): The Geology of the Sunwapta Pass Area, Jasper and Banff National Parks, Alberta. Part 2, Unpublished report, Park Library, Jasper, $51 \mathrm{p}$.

BAKER, R. G. (1976) : Late Quaternary vegetation history of the Yellowstone Lake basin, Wyoming, United States Geological Survey Professional Paper 729-E, $48 \mathrm{p}$.

BASSETT, I. J., CROMPTON, C. W., and PARMALEE, J. A. (1978): An Atlas of Airborne Pollen Grains and Common Fungus Spores of Canada, Research Branch, Canada Department of Agriculture, Monograph 18, $321 \mathrm{p}$.

BATES, C. D., COXON, P., and GIBBARD, P. L. (1978): A new method for the preparation of clay-rich sediment samples for palynological investigation, New Phytologist, Vol. 81, p. 459-463.

BEAUDOIN, A. B. (1984): Holocene environmental change in the Sunwapta Pass area, Jasper National Park, Unpublished Ph.D. Dissertation, The University of Western Ontario, $487 \mathrm{p}$.

BEAUDOIN, A. B., and KING, R. H. (1986): Using discriminant function analysis to identify Holocene tephras based on magnetite composition: a case study from the Sunwapta Pass area, Jasper National Park, Canadian Journal of Earth Sciences, Vol. 23, p. 804812.

FAEGRI, K., and IVERSEN, J. (1975): Textbook of Pollen Analysis, 3rd ed., Blackwell Scientific Pubs., Oxford, $295 \mathrm{p}$.

GARDNER, J. G., and JONES, N. K. (1985) : Evidence for a Neoglacial advance of the Boundary Glacier, Banff National Park, Alberta, Canadian Journal of Earth Sciences, Vol. 22, p. 1753-1756.
GREGOR, S., WIENS, D., STEVENS, R. E., and HAWKSWORTH, F. G. (1974): Pollination studies of Arceuthobium americanum in Utah and Colorado, The Southwestern Naturalist, Vol. 19, p. 6573.

HABEK, J. R., and MUTCH, R. W. (1973): Fire-dependent forests in the northern Rocky Mountains, Quaternary Research, Vol. 3, p. 408-424.

HOLLAND, W. D., and COEN, G. M., eds., (1982): Ecological (Biophysical) Land Classification of Banff and Jasper National Parks. Volume II: Soil and Vegetation Resources, Alberta Institute of Pedology, Pub. SS-82-44, 540 p.

JANZ, B., and STORR, D. (1977): The climate of the contiguous mountain parks, Project Report 30, Atmospheric Environment Service, Department of Environment, prepared for Parks Canada, $324 \mathrm{p}$.

KAPP, R. O. (1969): How to Know Pollen and Spores, Wm. C. Brown Co., Dubuque, lowa, $249 \mathrm{p}$.

KARLEN, W. (1983): Holocene fluctuations of the Scandinavian alpine tree-limit, in Tree-Line Ecology, P. MORISSET and S. PAYETTE, eds., Proceedings of the Northern Quebec Tree-Line Conference, Centre d'études nordiques, Université Laval, Québec, Collection Nordicana, No. 47 , p. 55-59.

KEARNEY, M. S. (1981): Late Quaternary vegetational and environmental history of Jasper National Park, Alberta, Unpublished Ph.D. Dissertation, The University of Western Ontario, $318 \mathrm{p}$.

(1982): Recent seedling establishment at timberline in Jasper National Park, Alta., Canadian Journal of Botany, Vol. 60, p. 2283 2287.

KEARNEY, M. S., and LUCKMAN, B. H. (1983): Holocene timberline fluctuations in Jasper National Park, Alberta, Science, Vol. 221, p. 261-263.

LaMARCHE, V. C., Jr. (1973): Holocene climatic variations inferred from treeline fluctuations in the White Mountains, California, Quaternary Research, Vol. 3, p. 632-660.

LUCKMAN, B. H. (1982): The Little Ice Age and oxygen isotope studies in the Middle Canadian Rockies, Report to Parks Canada, $31 \mathrm{p}$.

LUCKMAN, B. H., KEARNEY, M. S., and HOLLAND, D. K. (1977): Holocene environmental change in Jasper National Park, Report to Parks Canada, $17 \mathrm{p}$.

LUCKMAN, B. H., and OSBORN, G. D. (1979): Holocene glacier fluctuations in the Middle Canadian Rocky Mountains, Quaternary Research, Vol. 11, p. 52-77.

McANDREWS, J. H., BERTI, A. A., and NORRIS, G. (1973): Key to the Quaternary Pollen and Spores of the Great Lakes Region, Life Sciences Miscellaneous Pub., Royal Ontario Museum, Toronto, $61 \mathrm{p}$.

MAHER, L. J., Jr. (1963): Pollen analyses of surface materials from the southern San Juan Mountains, Colorado, Geological Society of America Bulletin, Vol. 74, p. 1485-1504.

(1972): Absolute pollen diagram of Redrock Lake, Boulder County, Colorado, Quaternary Research, Vol. 2, p. 531-553.

MARKGRAF, V. (1980): Pollen dispersal in a mountain area, Grana, Vol. 19, p. 127-146.

NELSON, J. G., and BYRNE, A. R. (1969): Fires, floods and National Parks in the Bow Valley, Alberta, in Vegetation, Soils and Wildlife, J. G. NELSON and M. J. CHAMBERS, eds., Methuen, Toronto, p. 45-58. 
OSBORN, G. (1982): Holocene glacier and climate fluctuations in the southern Canadian Rocky Mountains: A review, in Holocene Glaciers, W. KARLEN, ed., Striae, Vol. 18, p. 15-25.

PETERSEN, K. L., and MEHRINGER Jr., P. J. (1976): Postglacial timberline fluctuations. La Plata Mountains, southwestern Colorado, Arctic and Alpine Research, Vol. 8, p. 275-288.
TING, W. S. (1966): Determination of Pinus species by pollen statistics, California University Publications in Geological Science, Vol. 58, $182 \mathrm{p}$.

WESTGATE, J. A., and GORTON, M. P. (1981): Correlation techniques in tephra studies, in Tephra Studies, S. SELF and R. S. J. SPARKS, eds., D. Reidel, Dordrecht, The Netherlands, p. 73-94. 